\title{
UNIKANIE OPODATKOWANIA W ŚWIETLE ORZECZNICTWA NIEMIECKIEGO
}

\section{WPROWADZENIE}

W niemieckim systemie prawa podatkowego problem unikania opodatkowania sprowadza się w głównej mierze do pojęcia obejścia prawa podatkowego/ obejścia podatku (Steuerumgehung), które zachodzi w wyniku nadużycia możliwości kształtowania czynności prawnych. Niniejszy artykuł ma na celu przedstawienie dorobku orzeczniczego $\mathrm{w}$ zakresie unikania opodatkowania w Niemczech w oparciu o regulację ustawową i poglądy niemieckiej doktryny prawa podatkowego. Temat klauzuli ogólnej przeciwko unikaniu opodatkowania został już podjęty w polskiej literaturze, ale jedynie uzupełniająco doktryna polska przywoływała poglądy orzecznicze. Nadto nie wszystkie opracowania oparte zostały jednak na aktualnym stanie prawnym, tj. po 2008 r. ${ }^{1}$ Niniejszy artykuł ma zatem także za zadanie przybliżenie problemu po nowelizacji z 2008 r. ${ }^{2}$ Najważniejszą jego częścią jest natomiast analiza problemu w kontekście sądowego stosowania prawa.

\section{UNIKANIE OPODATKOWANIA A NIEMIECKI SYSTEM PODATKOWY}

Wskazać należy, że zgodnie z niemiecka doktryna prawa podatkowego ochrona przed obejściem prawa podatkowego nie stanowi tylko ochrony własnej państwa, ale jednocześnie jest to także ochrona osób trzecich ${ }^{3}$. Władza państwowa, aby wypełnić obowiązek ochrony, musi przedsięwziąć wystarcza-

${ }^{1}$ H. Litwińczuk, Problematyka obejścia podatku $w$ świetle doktryny $i$ orzecznictwa $w$ Niemczech $i$ w Polsce, w: Ex inuria non oritur ius. Ksiega ku czci Profesora Wojciecha Eqczkowskiego, Poznań 2003, s. 239; P. Karwat, Obejście prawa podatkowego: natura zjawiska i sposoby przeciwdziałania mu, Warszawa 2002; A. Kostecki, Klauzule generalne zapobiegania obejściu prawa podatkowego $w$ niemieckiej doktrynie i regulacjach prawnych, w: W. Miemiec (red.), Księga Jubileuszowa Profesora Ryszarda Mastalskiego. Stanowienie i stosowanie prawa podatkowego, Wrocław 2009, s. 257.

${ }^{2}$ Najszersze studium porównawczoprawne, które obejmuje co do zasady analizę jedynie ustawowej regulacji generalnej klauzuli przeciwko unikaniu opodatkowania w niemieckim systemie prawnym, zawarte jest w publikacji A. Olesińskiej, Klauzula ogólna przeciwko unikaniu opodatkowania, Toruń 2013.

${ }^{3}$ K.-D. Drüen, Unternehmerfreiheit und Steuerhumgehung, ,Steuer und Wirtschaft” 2008, nr 2, s. 154. 
jące normatywne i rzeczywiste środki, które doprowadzą do tego, że istnieć będzie odpowiednia i skuteczna ochrona przed obejściem prawa podatkowego ${ }^{4}$.

Ochrona przeciwko unikaniu opodatkowania (obejściu prawa podatkowego) jest zgodnym z prawem celem państwa, ale nie każdy środek może być uznany za uzasadniony do zabezpieczenia opodatkowania i w świetle zasady równości opodatkowania ${ }^{5}$. Ogólna klauzula przeciwko unikaniu opodatkowania (obejściu prawa podatkowego), zawarta w § 42 Abgabenordnung (dalej jako: AO), czyli niemieckim odpowiedniku polskiej ustawy - Ordynacja podatkowa, ma chronić przed unikaniem opodatkowania i umożliwiać to, żeby podatnik uiścił określona przez ustawę część dochodu państwa w imię solidarności wśród podatników ${ }^{6}$.

Zadaniem $§ 42 \mathrm{AO}$ jest to, aby urzeczywistnić cel ustawy podatkowej. Wskazuje się jednocześnie, że prawo podatkowe powinno jednak najpierw odpowiadać na problem obejścia prawa podatkowego za pomoca środków interpretacji teleologicznej i doskonalenia prawa przez wypełnianie luk ustawowych ${ }^{7}$. Dlatego też pytanie, czy $\S 42$ AO może mieć samodzielne znaczenie obok metody teleologicznej interpretacji ustaw podatkowych, jest dyskutowane w niemieckiej doktrynie prawa podatkowego. Tutaj należy postawić pytanie, czy potrzeba istnienia ogólnej klauzuli przeciwko unikaniu opodatkowania w porządku prawnym w ogóle występuje ${ }^{8}$. Niemiecka doktryna w tym zakresie wykształciła dwa kierunki myślenia, które zostaną przedstawione poniżej ${ }^{9}$.

Prezentacja obydwu stanowisk jest o tyle istotna, że nie dotyczą one tylko jednej odizolowanej kwestii na gruncie prawa podatkowego, jak np. generalna klauzula przeciwko unikaniu opodatkowania (§ $42 \mathrm{AO})$, ale sa one odbiciem daleko idącego podziału pomiędzy niemieckimi prawnikami (w tym zarówno przedstawicielami doktryny, jak i praktyki, a także poglądów orzecznictwa) w zakresie podejścia do prawa podatkowego ${ }^{10}$.

\section{Niemiecka „teoria interpretacji prawa podatkowego od wewnątrz” (Innentheorie)}

Tak zwana teoria interpretacji prawa podatkowego od wewnatrz (Innentheorie), za której twórcę uważa się Enno Beckera ${ }^{11}$, to podejście do problemu

4 Ibidem.

5 Ibidem.

${ }^{6}$ Ibidem.

7 J. Lang, Grundlagen der Steuerrechtsordnung, w: K. Tipke, J. Lang, Steuerrecht, Köln 2010, s. 163.

${ }^{8}$ W. Schön, Statutory Avoidance and Disclosure Rules in Germany, w: J. Freedman (red.), Beyond Boundaries Developing Approaches to Tax Avoidance and Tax Risk Management, Oxford 2008 , s. 48.

${ }^{9}$ M. Klein, A. Niemann, Abuse of Tax Law across Europe, „EC Tax Review” 2012, nr 2, s. 92; W. Schön, op. cit., s. 48 .

${ }^{10}$ Ibidem. W tym miejscu uzupełnić należy, że pierwsza grupa stoi na stanowisku, że nie występuje opodatkowanie, jeżeli prawodawca tego wyraźnie nie ustanowił, co ma na celu ochronę prawa podatnika do pewności prawa, aby mógł on rozsądnie kształtować swoje stosunki prawne; druga grupa stara się wzmocnić zasadę równości opodatkowania i dlatego akceptuje podejście, w którym zakres zastosowania normy prawa podatkowego może być rozszerzony w sposób, w jaki podatnik nie mógł tego przewidzieć.

11 Niemiecki prawnik, uznany za „ojca” aktualnie obowiązującego Abgabenordnung z 1977 r. 
ochrony systemu podatkowego przed unikaniem opodatkowania wskazujące na ochronę „od wewnątrz” przez wykładnię „obchodzonych” norm ${ }^{12}$.

Według znacznej części doktryny nie ma potrzeby zamieszczania w tekście ustawy podatkowej (nie ma potrzeby wprowadzania do systemu prawa pozytywnego) uregulowania przeciwko unikaniu opodatkowania, jak $§ 42$ AO, ponieważ te same rezultaty mogą zostać uzyskane przy zastosowaniu odpowiednich reguł interpretacyjnych przepisów materialnego prawa podatkowego ${ }^{13}$. Tak więc obejście prawa podatkowego może być zwalczane przez stosowanie interpretacji celowościowej (teleologiczna redukcja czy rozszerzenie) lub analogii (dane postanowienie ustawowe jest stosowane do faktów, których norma nie obejmuje swoim zakresem, ale swoim celem, intencja). Dlatego też rozwiązanie problemu obejścia prawa podatkowego staje się kwestią tego, czy zachowanie mające na celu obejście prawa podatkowego znajduje się w zakresie, czy poza zakresem zastosowania danego postanowienia ustawowego ${ }^{14}$.

W związku z powyższym $§ 42$ AO przypisuje się charakter czysto deklaratoryjny $^{15}$. Wskazuje się nadto, że przepis ten jest pusty i niepotrzebny ${ }^{16}$, ponieważ cel ustawy może zostać bez ograniczeń uwypuklony dzięki wykładni. Przez samą wykładnię ustawy można zapobiegać próbom obejścia ustawy podatkowej, w szczególności próbom „ogrania” celu ustawy przez wykorzystanie jej dosłownego brzmienia ${ }^{17}$. W konsekwencji § $42 \mathrm{AO}$ pełni tylko funkcję informacyjna ${ }^{18}$. Niemiecka „teorię interpretacji prawa podatkowego od wewnątrz” krytykuje się, że jeżeli zostałaby przyjęta i byłaby stosowana w praktyce, nowo stworzone metody unikania opodatkowania stałyby się wtedy niepewne ${ }^{19}$, sądownictwo otrzymałoby za dużą swobodę działania, co w konsekwencji doprowadziłoby do niepewności w planowaniu podatkowym ${ }^{20}$.

\section{Niemiecka „teoria interpretacji prawa podatkowego od zewnątrz" (Außentheorie)}

W doktrynie wykształcił się także drugi sposób myślenia o generalnej klauzuli przeciwko unikaniu opodatkowania (obejściu prawa podatkowego) „teoria interpretacji prawa podatkowego od zewnatrz” (Außentheorie). Za jej prekursora uważa się Alberta Hensla ${ }^{21}$.

${ }^{12}$ K.-D. Drüen, Steuerschuldverhältnis, Missbrauch von rechtlichen Gestaltungsmöglichkeiten, w: K. Tipke, H. W. Kruse, Abgabenordnung Finanzgerichtsordnung Kommentar, Köln 2011, s. 163 .

${ }^{13}$ W. Schön, op. cit., s. 48.

${ }^{14}$ M. Klein, A. Niemann, op. cit., s. 92; W. Schön, op. cit., s. 48.

${ }_{15}$ Chodzi także o to, że tekst przepisu zawiera stwierdzenie „kann nich”, a nie „darf nich”.

${ }_{16}$ K.-D. Drüen, Steuerschuldverhältnis..., s. 162.

17 Ibidem.

18 E. Ratshow, 2. Teil. Steuerschuldrecht, 2. Abschnitt. Steuerschuldverhältnis $\S 42$ AO, w: F. Klein, AO Abgabenordnung Kommentar 10. Auflage, München 2009, s. 272.

${ }^{19}$ A obniżenie obciążenia podatkowego może stanowić również cel wyboru określonych ukształtowań czynności prawnych; w takim przypadku taka możliwość mogłaby być ograniczona lub pozbawiona racji bytu.

20 E. Ratshow, op. cit., s. 272.

${ }^{21}$ M. Klein, A. Niemann, op. cit., s. 92. 
Zgodnie z tym ujęciem $\S 42 \mathrm{AO}$ jest poważnym instrumentem prawnym niezbędnym w celu odrzucenia czy zignorowania zachowania stanowiacego nadużycie, które musiałoby być zaakceptowane przez administracje podatkową i sądy w wypadku braku tego przepisu prawa pozytywnego ${ }^{22}$. Nie można w ogóle mówić o obejściu prawa podatkowego, jeżeli postanowienie ustawowe jest stosowane lub niestosowane za pomocą interpretacji czy analogii ${ }^{23}$, gdyż prawdziwe obejście ustawy podatkowej zaczyna się właśnie tam, gdzie sztuka wykładni zaczyna zawodzić. W konsekwencji należy $§ 42$ AO rozpatrywać jako normę zawierająca elementy stanu faktycznego i skutki prawne (jej stosowania). Tak jak każdą inną normę należy ją stosować przez subsumpcję stanu faktycznego do normy prawnej. Niemiecka „teoria interpretacji prawa podatkowego od zewnątrz" jest krytykowana, że $§ 42$ AO nie ma żadnej zawartości dającej się poddać subsumpcji, w szczególności nie da się wystarczająco skonkretyzować jego głównej cechy - „nadużycia” ${ }^{24}$.

Elementy wskazanej ogólnej klauzuli przeciwko unikaniu opodatkowania zostaną omówione w dalszej części artykułu. W tym miejscu, zauważyć jedynie należy, że $§ 42 \mathrm{AO}$ w aktualnym brzmieniu został wprowadzony na podstawie nowelizacji w 2008 r. Pierwotny kształt nowelizacji § 42 AO z 2008 r. był powszechnie krytykowany przez doktrynę prawa podatkowego ${ }^{25}$. Ostatecznie został przyjęty wariant, który stanowi podsumowanie dokonań orzecznictwa w tym zakresie ${ }^{26}$. Wydaje się, że $§ 42 \mathrm{AO}$ w aktualnym brzmieniu stanowi zatem wyraz długotrwałego procesu kształtowania się pojęcia obejścia prawa podatkowego (Steuerumgehung) i charakterystycznych dla niego elementów, co uzasadnia odwołanie się do ustawowego brzmienia $\S 42 \mathrm{AO}$ i poglądów doktryny komentujacych jego zastosowanie. Nadto przedstawiony zostanie element rozwojowy orzecznictwa niemieckiego w zakresie unikania opodatkowania, jakim jest koncepcja „całkowitego planu” (Gesamptplan).

\section{Zgodność generalnej klauzuli przeciwko unikaniu opodatkowania (§ $42 \mathrm{AO})$ z Ustawą zasadniczą Republiki Federalnej Niemiec}

Zastosowanie $§ 42$ AO nie było nigdy kwestionowane przez niemiecki sąd najwyższy właściwy w sprawach podatkowych (Bundesfinanzhof) i nie było nigdy wprost badane przez niemiecki Federalny Trybunał Konstytucyjny (Bundesverfassungsgericht $)^{27}$. Z kolei w literaturze ${ }^{28}$ zgodnie podnosi się, że $\S 42 \mathrm{AO}$ jest zgodny z Ustawą zasadniczą ${ }^{29}$, jednak nie jest on optymalnym rozwiązaniem.

${ }^{22}$ W. Schön, op. cit., s. 48.

${ }^{23}$ M. Klein, A. Niemann, op. cit., s. 92 .

${ }^{24}$ E. Ratshow, op. cit., s. 272.

${ }^{25}$ G. Crezelius, Vom Missbrauch zum Misstrauen: Zur geplanten Änderung des $\S 42$ AO, „Der Betrieb" 2007, z. 26, s. 1428-1430.

${ }^{26}$ K.-D. Drüen, Steuerschuldverhältnis..., s. 138 .

${ }^{27}$ E. Ratshow, op. cit., s. 274.

${ }^{28}$ Najciekawsze opracowanie w tym kontekście to: Ch. Lenz, T. Gerhard, Das Grundrecht auf steueroptiemierende Gestaltung, „Betriebs-Berater” 2007, z. 45, s. 2429-2434.

${ }^{29}$ Grundgesetz für die Bundesrepublik Deutschland z 23 maja 1949 r., BGBl. I, 1 (Ustawa zasadnicza Republiki Federalnej Niemiec); E. Ratshow, op. cit., s. 273; K.-D. Drüen, Steuerschuldverhältnis, op. cit., s. 167. 
W doktrynie wskazuje się, że generalna klauzula zawarta w $§ 42$ AO jest odpowiednim, celowym i, przy restryktywnym stosowaniu przez sądy podatkowe, proporcjonalnym środkiem w walce z unikaniem opodatkowania (obejściem prawa podatkowego ${ }^{30}$. W przeciwieństwie do projektu nowelizacji $\S 42 \mathrm{AO}$ (występującego w literaturze niemieckiej pod nazwą Referentenentwurf ${ }^{31}$ ), który wprowadzał obalalne ustawowe domniemanie wystapienia nadużycia możliwości kształtowania czynności prawnych i przeniesienie ciężaru dowodu na podatnika ${ }^{32}$, w aktualnym brzmieniu $\S 42$ AO jest skonkretyzowaniem i skodyfikowaniem opartego na kazuistyce dotychczasowego orzecznictwa sąów podatkowych ${ }^{33}$. Uregulowanie odpowiada w wystarczajacy sposób wymaganiom sformułowanym przez zasadę określoności (art. 20 ust. 3 Ustawy zasadniczej). Nadto art. 3 ust. 1 Ustawy zasadniczej wymaga rzeczywistego i ustawowego równomiernego obciążenia podatników. W tym zakresie problem obejścia ustawy podatkowej jest konstytucyjnie relewantny ${ }^{34}$. Podnosi się, że obrona przed obejściem ustaw jest zadaniem wszystkich władz państwowych $^{35}$, w szczególności ustawodawcy i administracji ${ }^{36}$.

Wskazuje się ponadto, że omawiana regulacja nie stanowi naruszenia możliwości kształtowania zachowań podatników w sposób optymalny podatkowo ${ }^{37}$, jeżeli przez interpretację zakaz nadużycia kształtowania ich czynności nie zostanie przekształcony w zakaz kształtowania tych czynności w ogóle ${ }^{38}$.

Problem konstytucyjności § 42 AO na gruncie niemieckiego systemu prawnego jest interesujacy w ujęciu porównawczym ze względu na orzecznictwo polskiego Trybunału Konstytucyjnego w zakresie występowania w polskim systemie prawnym ogólnej klauzuli przeciwko obejściu prawa podatkowego oraz głosów doktryny w tym zakresie ${ }^{39}$.

30 E. Ratshow, op. cit., s. 273.

31 Projekt zmiany Abgabenordnung, tj. Referentenentwurf z 14 czerwca 2007 r.

32 K.-D. Drüen, Steuerschuldverhältnis..., s. 138.

${ }^{33}$ Wyrok BFH z 22 sierpnia 1952 r., BFH IV 246/50, BStBl. III 1951, 181; wyrok BFH z 10 listopada 1983 r., BFH IV R 62/82, BFHE 141, 12, BStBl. II 1984, 605; wyrok BFH z 13 grudnia 1983 r., BFH VIII R 173/83, BStBl. 1984, II, 428; wyrok BFH z 14 maja 1986 r., BFH II R 22/84, BFHE 146, 480 BStBl. 1986 II, 620; wyrok BFH z 4 sierpnia 1987 r., BFH V B 16/87, BFHE 150, 478, BStBl. II 1987, 756; wyrok BFH z 23 lutego 1989 r., BFH V B 60/88, BFHE 155, 503, BStBl. II 1989, 396; wyrok BFH z 25 stycznia 1994 r., BFH IX R 97, 98/90, BFHE 174, 386, BStBl II 1994, 738; wyrok BFH z 27 lipca 1999 r., BFH VIII R 36/98, BFHE 189, 408, BStBl. II 1999, 769; wyrok BFH z 19 sierpnia 1999 r., BFH I R 77/96, BFHE 189, 342, BStBl. II 2001, 43; wyrok BFH z 19 stycznia 2000 r., BFH I R 94/97, BStBl. II 2001, 222; wyrok BFH z 23 sierpnia 2000 r., BFH I R 4/97, BStBl. 2001, II, 260.

${ }^{34}$ E. Ratshow, op. cit., s. 273.

35 Ibidem.

${ }^{36}$ K.-D. Drüen, Steuerschuldverhältnis..., s. 167.

37 Jeżeli „inne niepodatkowe przyczyny” nie będą interpretowane zawężająco.

38 Ch. Lenz, T. Gerhard, op. cit., s. 2434; wydaje się jednak, że autorzy nieprawidłowo określają możliwość kształtowania czynności prawnych jako „prawo podstawowe” podatnika wywodzone $\mathrm{z}$ art. 2 ust. 1 Ustawy zasadniczej.

${ }^{39}$ Wyrok TK z 18 maja 2005 r., K 16/04, Dz. U. z 31 maja 2005 r., Nr 95, poz. 806; i wskazane tam przesłanki, jakie muszą być spełnione, aby uregulowanie podobne do $§ 42$ AO mogło obowiązywać na gruncie polskiego systemu prawnego - wydaje się, że spełnienie przesłanek konstytucyjnych nie jest możliwe. 


\section{Interpretacja gospodarcza ustaw podatkowych}

$\mathrm{Na}$ gruncie niemieckiego prawa podatkowego wykształciło się także interesujące podejście do interpretacji ustaw podatkowych. Celem jego prezentacji jest przybliżenie sposobu analizy przepisów prawa podatkowego, który także nie jest obcy polskiemu systemowi prawnemu ${ }^{40}$.

Ustawy podatkowe wiążą się z procesami gospodarczymi i generalnie stanem gospodarki i wymagają zatem szczególnej interpretacji gospodarczej (wirtschaftliche Betrachtungsweise). Nie jest to żadna specjalna metoda interpretacji prawa podatkowego, ale interpretacja teleologiczna ustaw, ponieważ ustawy podatkowe służą obciążeniu procesów gospodarczych podatkami. Dlatego większość pojęć prawnopodatkowych a priori można interpretować jedynie w kontekście ich charakteru gospodarczego. Dodatkowo zapożyczone przez ustawodawcę pojęcia prawa cywilnego muszą być dostosowywane teleologicznie do celów ustaw podatkowych, ponieważ prawu cywilnemu i prawu podatkowemu za podstawę służą różne teleologie, a wykładnia teleologiczna tych samych pojęć może doprowadzić do innych rezultatów ${ }^{41}$.

W zakresie rozbieżności pomiędzy zachowaniem gospodarczym a stanem prawnym wskazać natomiast należy, że prawo podatkowe nie nawiązuje do prawnego charakteru czynności prawnych; zasadniczo ważniejsza jest gospodarcza interpretacja stanu faktycznego. Gdy występuje sytuacja, w której czynność prawna i jej gospodarcza realizacja „rozchodzą się”, opodatkowanie zależy od tego, co zostało gospodarczo zrealizowane. Również tutaj interpretacja gospodarcza, która za podstawę opodatkowania poczytuje gospodarcze ,jest”, jest refleksem przywiązania do wydajności gospodarczej ${ }^{42}$.

\section{GENERALNA KLAUZULA PRZECIWKO UNIKANIU OPODATKOWANIA W NIEMIECKIM PRAWIE PODATKOWYM (§ 42 AO)}

Aktualnie na gruncie niemieckiego systemu prawnego uregulowanie generalnej klauzuli przeciwko obejściu prawa podatkowego odnaleźć można - jak już wspomniano - $\mathrm{w} \S 42 \mathrm{AO}^{43}$. Taki przepis jest nazywany w międzynarodowym żargonie komparatystycznym na gruncie prawa podatkowego generalna klauzula przeciwko unikaniu opodatkowania (General Anti-Avoidance

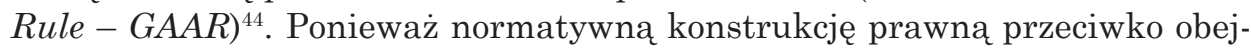

${ }^{40}$ Por. A. Mudrecki, Wyktadnia gospodarcza w orzecznictwie Naczelnego Sadu administracyjnego, w: M. Münnich, A. Zdunek (red.), Stanowienie $i$ stosowanie prawa podatkowego $w$ Polsce. Optymalizacja podatkowa a obejście prawa podatkowego, Lublin 2012, s. 135.

${ }^{41}$ J. Lang, op. cit., s. 157.

${ }^{42}$ Ibidem, s. 159.

${ }^{43}$ P. Kirchhof, Gestaltungsfreiheit und Belastungsgleichheit als Grundlagen des Steuerrechts, w: R. Hüttemann (red.), Gestaltungsfreiheit und Gestaltungsmissbrauch im Steuerrecht, Deutsche Steuerjuristische Gesellschaft, t. 33, Köln 2010, s. 22-23.

${ }^{44}$ W. Schön, Legalitat, Gestaltungsfreiheit und Belastungsgleichheit als Grundlagen der Besteuerung, w: R. Hüttemann (red.), op. cit., s. 58. 
ściu prawa podatkowego oparto na istniejącym przed 2008 r. orzecznictwie Bundesfinanzhofu, a także na opracowaniach doktryny, uzasadnione jest, aby w analizie aktualnie obowiązującego $§ 42$ AO wykorzystać także krytyczne opinie doktryny.

Zgodnie z $§ 42$ ust. 1 AO przez nadużycie możliwości kształtowania czynności prawnych nie można obejść ustawy podatkowej. Jeżeli spełniony jest prawnopodatkowy stan faktyczny z ustaw szczególnych, który służy zapobieganiu obejścia ustawy podatkowej, skutki prawne określone sa wtedy zgodnie $\mathrm{z}$ tym przepisem. W przeciwnym razie zobowiązanie podatkowe powstaje w wyniku zajścia nadużycia w znaczeniu nadanym przez ust. 2 tak, jakby ono powstało przy zaistnieniu ukształtowania czynności prawnych, które byłyby właściwe, stosowne i adekwatne do rzeczywistych procesów gospodarczych.

Zgodnie z ust. $2 \S 42$ AO nadużycie występuje, gdy zostanie wybrane niewłaściwe prawne ukształtowanie czynności, które przy porównaniu z właściwym, stosownym ukształtowaniem czynności prawnych przynosi podatnikowi lub osobie trzeciej ustawowo nieprzewidzianą korzyść podatkowa. Przepis ten nie znajduje zastosowania w sytuacji, kiedy podatnik wskaże pozapodatkowe przyczyny wybranego ukształtowania czynności prawnych, które są znaczące, biorąc pod uwagę całokształt stosunków.

Reprezentatywnym przykładem wpływu orzecznictwa Bundesfinanzhofu na nowelizację z 2008 r. wydaje się, że jest wyrok z 25 stycznia 1994 r. (IXR 97, 98/90) ${ }^{45}$, w którym stwierdzono, iż nadużycie możliwości kształtowania czynności prawnych ma miejsce, kiedy została wybrana czynność prawna, która stosownie do obranego celu jest nieadekwatna, powinna ona służyć zmniejszeniu podatku, a gospodarcze i inne poważne przyczyny jej nie uzasadniają ${ }^{46}$. Ponadto na uwagę zasługuje orzeczenie Bundesfinanzhofu z 19 czerwca $1991 \mathrm{r}$. (IX R 134/86) ${ }^{47}$, zgodnie z którym nierozstrzygnięte jest, czy stwierdzenie, że miało miejsce nadużycie kształtowania czynności prawnych, zakłada również to, że istniał zamiar stron umów ${ }^{48}$. W wyroku Bundesfinanzhofu z 27 lipca 1999 r. (VIII R 36/98) ${ }^{49}$ zostało także wskazane, że trzy cechy charakterystyczne: 1) nieadekwatność ukształtowania czynności prawnych, 2) mająca na celu obniżenie zobowiązania podatkowego, 3) bez wystapienia gospodarczych lub innych ważnych przyczyn takiego ukształtowania czynności prawnych, musza zachodzić kumulatywnie ${ }^{50}$.

W doktrynie podnosi się generalnie, że formuły nadużycia doprowadzaja do niepewności, osłabiają związanie ustawa, prowadzą do nieprzewidywalności skutków prawnych. Podatnik przedstawia podatkowo wyraźny stan fak-

${ }^{45}$ Wyrok BFH z 25 stycznia 1994 r., BFH IX R 97, 98/90, BFHE 174, 386, BStBl. II 1994, 738.

${ }^{46}$ G. Rose, K. Glorius-Rose, Steuerplanung und Gestaltungsmissbrauch. Eine Auswertung der jüngeren Rechtsprechung des BFH zu $\$ 42$ AO, Bielefeld 2002, s. 28-29.

${ }_{47}$ Wyrok BFH z 19 czerwca 1991 r., BFH IX R 134/86, BFHE 164, 498, BStBl. II 1991, 904.

${ }^{48}$ G. Rose, K. Glorius-Rose, op. cit., s. 27.

${ }^{49}$ Wyrok BFH z 27 lipca 1999 r., VIII R 36/98, BFHE 189, 408, BStBl. II 1999, 769.

${ }^{50}$ G. Rose, K. Glorius-Rose, op. cit., s. 31, także dalsze wyroki np. wyrok BFH z 14 stycznia 2003 r., BFH IX R 5/00, BFHE 201, 246, BStBl. II 2003, 509; wyrok z 26 marca 1996 r., BFH IX R 51/92, BFHE 180, 330, BStBl. II 1996, 443; wyrok BFH z 17 grudnia 2003 r., BFH IX R 8/98, $\mathrm{BFH} / \mathrm{NV} 2004,939$. 
tyczny inaczej, niż należy rozumieć ten stan zgodnie z zasadami legalizmu i równości przed ustawa, z nieuniknionym skutkiem opodatkowania jako cena wolności prawnopodatkowej ${ }^{51}$.

To elementarne podatkowe pytanie o uzasadnienie występowania w prawie pozytywnym generalnej klauzuli przeciwko obejściu ustawy podatkowej jest bardziej wyraziste po nowelizacji z 2008 r.; chodzi tutaj o definicję legalna wyrażenia „nadużycie możliwości kształtowania czynności” z § 42 ust. 2 zd. 1 AO. Ten przepis dla stwierdzenia nadużycia prawa, czyli niestosownego prawnego ukształtowania czynności prawnych, wymaga porównania, przez które odkrywa się ustawowo nieprzewidzianą korzyść podatkową. Stwierdzenie nadużycia i przeciwdziałanie mu prowadzi zatem z powrotem do wystapienia praworządności i równości ustawowej, ukróca korzyść podatkowa, której nie przewiduje czy nie usprawiedliwia ustawowo określony powód obciążenia podatkiem ${ }^{52}$.

Niestosowne prawne ukształtowanie czynności prawnych, dla których nie można przywołać żadnych poważnych innych niż podatkowe przyczyn, będa tak opodatkowane, jakby zostało wybrane ukształtowanie czynności prawnych stosowne do procesów gospodarczych ${ }^{53}$, dzięki czemu w sytuacjach uznania za nadużycia ustawodawca przydziela sądom i organom podatkowym możliwość zastosowania skutków prawnych materialnej normy prawa podatkowego poza w niej określony prawnopodatkowy stan faktyczny czy zastosowania norm materialnego prawa podatkowego do fikcyjnego stanu faktycznego ${ }^{54}$.

Do czasu nowelizacji $\S 42$ AO kwestia tego, jaką rolę pełni element subiektywny, była sporna ${ }^{55}$. Zatem należałoby zadać pytanie, czy istnieje potrzeba, aby obok obiektywnego elementu niewłaściwości ukształtowania czynności prawnych również występował zamiar nadużycia. Podczas gdy Pierwszy i Trzeci Senat Bundesfinanzhofu w swoim stałym orzecznictwie ${ }^{56}$ wymagały zamiaru nadużycia, który można przypuścić w drodze przedstawienia dowodów poszlakowych, kiedy wybrane ukształtowanie czynności prawnych jest niewłaściwe, Piąty Senat Bundesfinanzhofu ${ }^{57}$ z góry odrzucał podejście obejmujące wymóg zamiaru ${ }^{58}$.

Nieważne są rzeczywiste subiektywne przyczyny postępowania, z powodu których podatnik wybrał dane ukształtowanie czynności prawnych, będące (potencjalnie) nadużyciem; decydujące jest jedynie to, jak dane ukształtowanie czynności prawnych widzi obiektywnie oceniający. Należy szczególnie zaakcentować nieuwzględnianie motywu postępowania podatnika ${ }^{59}$. Opowie-

51 P. Kirchhof, op. cit., s. 22-23.

52 Ibidem.

${ }^{53}$ W. Schön, Legalität..., s. 58.

54 Ibidem.

${ }_{55}$ M. Klein, A. Niemann, Abuse of Tax Law across Europe (Part One), „EC Tax Review” 2010, nr 2, s. 93.

56 Wyrok BFH z 5 lutego 1992 r., BFH I R 127/90, BStBl. II 1992, 532 (536); wyrok BFH z 24 listopada 2000 r., BFH III R 25/02, BStBl. II 2004, 787 (792).

${ }^{57}$ Wyrok BFH z 23 lutego 1989 r., V B 60/88, BStBl. II 1989, 396 (399); wyrok BFH z 10 września 1992 r., V R 104/91, BStBl. II 1993, 253 (255).

58 J. Hey, Spezialgesetzliche Missbrauchsgesetzgebung, „Steuer und Wirtschaft” 2005, nr 2, s. 169 .

59 A. Leisner-Egensperger, Steuerumgehung i.S.d. par. 42 AO nach der Reform, „Deutsche Steuer-Zeitung” 2008, nr 11. 
dzieć zatem należy się za obiektywnym postrzeganiem zachowań podatników. Podatnikowi nie musi zostać wykazany zamiar obejścia ustawy podatkowej ${ }^{60}$.

Jednakże z drugiej strony częściowo należy brać pod uwagę motywy ukształtowania czynności prawnych, gdyż § 42 ust. 2 zd. 2 AO umożliwia jednoznacznie podatnikowi przeprowadzenie dowodu występowania poważnych niepodatkowych podstaw określonego ukształtowania czynności prawnych. Podatnik może zwolnić się od odpowiedzialności, jeżeli wykaże pozapodatkowe motywy swojego zachowania ${ }^{61}$.

Wykazywane przez podatnika pozapodatkowe podstawy ukształtowania czynności prawnych muszą być poważne na tle ogólnego obrazu stosunków prawnych ${ }^{62}$. Element „poważności” niepodatkowych podstaw ukształtowania czynności prawnych może być potencjalnie konfliktogenny ${ }^{63}$. Z punktu widzenia procesowego takie sformułowanie $§ 42$ AO wprowadza nowy obowiązek dowodzenia, dlatego wskazuje się, że ma tutaj miejsce częściowe odwrócenie ciężaru dowodu w kierunku podatnika ${ }^{64}$. Oczywiste jest jednak aktualnie, że ciężar udowodnienia obejścia ustawy podatkowej w kształcie wyznaczonym przez $\S 42$ AO spoczywa na organach podatkowych (był to główny element wcześniejszej szerokiej krytyki ze strony niemieckiej doktryny).

\section{SĄDOWE PODEJŚCIE DO UNIKANIA OPODATKOWANIA - KONCEPCJA „CAŁKOWITEGO PLANU” (GESAMTPLAN)}

Przyjęcie, że doszło do ukształtowania czynności prawnych stanowiącego nadużycie, wymaga obecności zachowań mających na celu obejście ustawy podatkowej. W takim układzie podatnik, aby ukryć nadużycie ukształtowania czynności prawnych, dokonuje często wielu czynności prawnych (tzw. omijające, poprawiajace, poboczne, postronne czynności prawne), jak np. darowizna i zwrot darowanej kwoty w drodze pożyczki, darowizna powiązana (chodzi tutaj np. o sytuację, w której rodzice, chcąc docelowo dokonać darowizny na rzecz małżonka swojego dziecka, najpierw darują rzecz swojemu dziecku, aby ono darowało ją później swojemu współmałżonkowi), czy „włączenie” osoby trzeciej do dokonywanych transakcji ${ }^{65}$.

Dlatego orzecznictwo wykształciło takie podejście do działań podatnika, zgodnie z którym rozstrzyga sprawy z zakresu obejścia ustawy podatkowej, mając na uwadze „całkowity plan” (Gesamtplan) podatnika, który obejmuje ciag wydarzeń. W niemieckiej literaturze przedmiotu jest to „orzecznictwo dotyczące całkowitego planu” (Gesamtplanrechtsprechung) ${ }^{66}$. Przyjęcie koncepcji

60 J. Hey, op. cit., s. 169.

${ }^{61}$ M. Klein, A. Niemann, Abuse of Tax (Part One), s. 94.

62 A. Leisner-Egensperger, op. cit.; M. Klein, A. Niemann, Abuse of Tax (Part One), s. 94.

63 J. Hey, op. cit., s. 169.

${ }^{64}$ A. Leisner-Egensperger, op. cit.

65 „Ausweich-, Korektur-, Neben- und Seitengeschaefte (Schenkung und Ruckgewahr des geschenkten Betrages per Darlehen, Kettenschenkung, Einschalten Dritten etc.)”.

${ }^{66}$ K. Tipke, J. Lang, op. cit., s. 166. 
„całkowitego planu” oznacza zatem taki pogląd sądów podatkowych, zgodnie z którym większa liczba czynności prawnych oparta na spójnym planie i będąca w ścisłym związku czasowym i przedmiotowym dla celów oceny podatkowej ma być rozpatrywana jako jeden całościowy proces gospodarczy, który zostaje następnie poddany subsumpcji ${ }^{67}$.

Poniżej przedstawione zostaną cechy charakterystyczne koncepcji „całkowitego planu" jako elementu rozwojowego wyinterpretowanego z § $42 \mathrm{AO}$ przez Bundesfinanzhof, gdyż, co należy również wskazać, koncepcja ta stanowi element prawnopodatkowego stanu faktycznego zawartego w omówionym przepisie $^{68}$.

W pierwszej kolejności należy zadać pytanie, czy koncepcja „całkowitego planu" usamodzielniła się jako niezależny prawnopodatkowy stan faktyczny poza zakres unormowania $\S 42$ AO. Jak wskazał Bundesfinanzhof, nie tylko z powodów prawnosystemowych, lecz także ze względu na jego dotychczasowe orzecznictwo $^{69}$, należy na tak zadane pytanie odpowiedzieć jednoznacznie, że tak nie jest. Nie wymaga to również dalszego wyjaśniania. Sądownie zaakceptowana koncepcja „całkowitego planu” służy temu, żeby wypełnić treścia $\S 42 \mathrm{AO}^{70}$. Taki pogląd znajduje także uzasadnienie w wyroku Pierwszego Senatu Bundesfinanzhofu ${ }^{71}$.

Pierwszą przesłanką ujawniającą możliwość występowania „całkowitego planu" jest przyjęcie wcześniejszego nakierowanego na określony cel planu. Podatnik chce stworzyć taką sytuację na końcu ostatniej części składowej, i to ex ante, tzn. od początku pierwszej części składowej, która miałaby przyczynić się do zmniejszenia wysokości podatku do zapłaty. Taki plan obejmuje wszystkie istotne części składowe, łącząc je w jedną całość, przez co usprawiedliwia ich łączna, całościową analizę. Jednak nie jest wymagane, żeby poszczególne części składowe odnosiły się explicite jedna do drugiej. Wystarcza, aby ich przeprowadzenie było wcześniej przewidziane. Poszczególne części składowe maja tylko takie znaczenie, że wspomagają one jego zrealizowanie $^{72}$.

W związku z tym sądy odmówiły oparcia rozstrzygnięcia na koncepcji „całkowitego planu”, jeżeli występowały gospodarcze lub godne uznania podatkowe przyczyny poszczególnych części składowych, a podatnikowi chodziło o konsekwencje tych części składowych ${ }^{73}$. Postrzeganie obejmujace wszystkie części składowe ustępuje również wtedy, kiedy poszczególne części składowe

${ }^{67}$ G. Foerster, D. Schmidtmann, Die Gesamtplanrechtsprechung im Steuerrecht mit einem Vergleich der sog. „Step transaction doctrine” im amerikanischen, britischen und belgischen Steuerrecht, „Steuer und Wirtschaft” 2003, nr 2, s.114; wyrok BFH z 27 października 2005 r., BFH IX R 76/03, BStBl. 2006 II, 359.

68 Np. postanowienie BFH z 19 stycznia 2011 r., X B 43/10, BFH/NV 2011, 636.

69 Por. wyrok BFH z 13 października 1992 r., VIII R 3/89, BFHE 169, 336, BStBl. II 1993, 477; wyrok BFH z 26 marca 1996 r., IX R 51/92, BFHE 180, 330, BStBl. II 1996, 443; wyrok BFH z 13 października 1993 r., X R 81/91, BFH/NV 1994, 620.

70 Postanowienie BFH z 19 stycznia 2011 r., X B 43/10, BFH/NV 2011, 636.

71 Wyrok BFH z 25 listopada 2009 r., I R 72/08, BFHE 227, 445, BStBl. II 2010, 471.

72 G. Foerster, D. Schmidtmann, op. cit., s. 120.

73 Wyrok BFH z 9 listopada 2000 r., IV R 60/99, BStBl. II 2001, 101 (102). 
nie odnoszą się do tego samego dobra ekonomicznego ${ }^{74}$. Wszystkie istotne części składowe „całkowitego planu” muszą być ustalone ex ante, tzn. od początku pierwszej części składowej. W przeciwnym razie nie da się uzasadnić rozpatrywania danego przypadku obejmującego wszystkie części składowe ${ }^{75}$. Istnienie „całkowitego planu” może wypływać z uprzednio zawartych ustaleń umownych (kontraktowych) ${ }^{76}$ czy z uzgodnień w szczególnej formie ${ }^{77}$ dotyczących wszystkich istotnych części składowych.

Stwierdzenie bez watpliwości, że wystapił „całkowity plan” przygotowany ex ante, jest rzadko możliwe, dlatego też należy sięgać po cechy szczególne, które uwidaczniają się na zewnątrz jako oznaki dowodowe ${ }^{78}$. Jako zewnętrzna oznaka dowodowa istnienia „całkowitego planu” od początku trwania wydarzenia jest przez orzecznictwo przywoływany czasowy i gospodarczy czy rzeczowy związek pomiędzy urzeczywistnionymi częściami składowymi ${ }^{79}$.

Rzeczowy i gospodarczy związek różnych części składowych całościowego wydarzenia uzasadniany będzie całościowym dopasowaniem poszczególnych części składowych do nadrzędnego końcowego celu. Jako taki nadrzędny cel końcowy w orzecznictwie przywołane zostanie np. zbycie przedsiębiorstwa, części przedsiębiorstwa lub udziałów w przedsiębiorstwie, restrukturyzacja grupy spółek ${ }^{80}$.

Cechy charakterystyczne rzeczowego i czasowego związku pomiędzy większą ilością części składowych „całkowitego planu” pozostają pomiędzy soba w ograniczonym stosunku subsumcji, co oznacza, że w przypadku widocznego rzeczowego związku zmniejsza się wymóg związku czasowego i vice ver$s a$ - krótki okres pomiędzy czynnościami składowymi będzie oceniany jako przesłanka dla rzeczowej zależności czynności. Im krótszy wydaje się przedział czasu pomiędzy poszczególnymi częściami składowymi, tym trudniej obalić będzie domniemanie istnienia wcześniejszego, nakierowanego na określony cel planu ${ }^{81}$.

Niewyjaśnionym pozostaje to, w jaki sposób pojęcie związku czasowego należałoby definiować. Wydaje się, że decydującym wymogiem czasowego związku poszczególnych części składowych „całkowitego planu” powinna być gospodarcza waga całościowych środków. Im cięższe środki, tym mniej znaczne są wymagania czasowego związku poszczególnych części składowych odnośnie do domniemania wystapienia „całkowitego planu” i vice versa. Dla mniej obciążajacych całościowych środków musi być dlatego wyraźnie zauważalny m.in. krótszy wymagany związek czasowy, aby usprawiedliwić domniemanie wystapienia „całkowitego planu”82. Przykładowo Bundesfinanzhof zgodził się

74 G. Foerster, D. Schmidtmann, op. cit., s. 120.

75 Ibidem, s. 121.

76 Wyrok BFH z 22 stycznia 2002 r., VIII R 46/00, BStBl. II 2002, 685.

77 Wyrok BFH z 13 października 1992 r., VIII R 3/89, BStBl. II 1993, 477.

78 G. Foerster, D. Schmidtmann, op. cit., s. 121.

${ }^{79}$ Wyrok BFH z 1 sierpnia 2002 r., V R 17/01, BFH/NV 2003, 271.

${ }^{80}$ G. Foerster, D. Schmidtmann, op. cit., s. 121; L. Brinkmann, Teilentgeltliche Unternehmensnachfolge im Mittelstand, Berlin 2005, s. 31.

${ }^{81}$ G. Foerster, D. Schmidtmann, op. cit., s. 121; L. Brinkmann, op. cit., s. 31.

82 Ibidem. 
z tym, że „całkowity plan” wystapił w przypadku sukcesji przedsiębiorstwa, która miała miejsce w czasie 25 miesięcy, licząc pomiędzy pierwszą a ostatnią częścią składową „całkowitego planu”, jednakże ważnym elementem był także fakt, że w pomiędzy pierwszą a ostatnią czynnością wystąiła jego inna część składowa ${ }^{83}$.

Koncepcja „całkowitego planu” zakłada, że obok zaistnienia wcześniejszego, obejmującego wszystkie części składowe i nakierowanego na końcowy cel planu, istnieje także zdolność wprowadzenia w życie, przeprowadzenia części składowych. Tutaj leży również decydująca różnica koncepcji „całkowitego planu", gdy działający w zaplanowany sposób podatnik odrzuca ryzyko występujące w stosunku z drugą stroną umowy, z sytuacją na rynku, stanem środowiska go otaczającego. Tylko kiedy poszczególne części składowe zostana wprowadzone w życie w celu wdrożenia „całkowitego planu”, uzasadnione jest, aby wskazane części składowe scalić w jedną całość ${ }^{84}$.

Rzeczywiste przeprowadzenie „całkowitego planu” i wystapienie zamierzonego rezultatu końcowego są konieczne, aby przyjąć „całkowity plan” za podstawę subsumpcji, ponieważ inaczej nie da się uzasadnić rozważania obejmującego poszczególne części składowe, które zostały „ustawione”, aby osiagnaćc zaplanowany, możliwy cel końcowy. Jeżeli nie osiagnie się sukcesu (tzn. wprowadzenie w życie „całkowitego planu” się nie uda), rezultat nie będzie korespondował nie tylko z pierwotnym planem, lecz także z urzeczywistnionymi częściami składowymi w taki sposób, że nie wystapi żaden całościowy proces gospodarczy, a skutków prawnych nie będzie można łączyć ze spiętym klamrą całościowym stanem faktycznym. Poza tym zniweczony „całkowity plan” wskazuje na brak rzeczywistej możliwości wprowadzenia w życie zaplanowanych części składowych ${ }^{85}$.

Zastosowanie przez sądy w orzecznictwie omawianej koncepcji (Gesamtplanrechtsprechung) nie wpływa na części składowe „całkowitego planu” na gruncie prawa cywilnego ${ }^{86}$.

Powiązanie rzeczywistych części składowych w jedność gospodarczą może zostać zastosowane na niekorzyść lub na korzyść podatnika ${ }^{87}$.

\section{WNIOSKI}

Niemiecki system podatkowy reprezentuje model przeciwdziałania obejściu ustawy podatkowej, w którym najważniejsze znaczenie przypisuje się ustawowej regulacji ogólnej klauzuli (§ 42 AO). Orzecznictwo Bundesfinanzhofu miało doniosłe znaczenie w toku wprowadzania w życie nowelizacji § 42 AO z 2008 r.

\footnotetext{
83 Wyrok BFH z 12 kwietnia 1989 r., I R 105/85, BStBl. II, 1989, 653-655.

${ }^{84}$ G. Foerster, D. Schmidtmann, op. cit., s. 121; L. Brinkmann, op. cit., s. 31.

85 Ibidem.

${ }^{86}$ Wyrok BFH z 6 marca 1996 r., II R 38/93, BStBl. II, 1996, 279; L. Brinkmann, op. cit., s. 33.

${ }^{87}$ G. Foerster, D. Schmidtmann, op. cit., s. 121; L. Brinkmann, op. cit., s. 31.
} 
Aktualna treść normatywna wskazanego przepisu stanowi przeniesienie tez z orzecznictwa Bundesfinanzhofu na grunt ustawowy. Wydaje się, że regulacja ustawowa odzwierciedla zwycięstwo patrzenia na kwestie unikania opodatkowania w Niemczech zgodnie z „teorią interpretacji prawa podatkowego od zewnątrz" (Außentheorie).

Ponadto rozwinięty w orzecznictwie Bundesfinanzhofu pogląd o możliwości scalania szeregu czynności dokonanych na gruncie prawa cywilnego w celu ich opodatkowania jako całość (Gesamtplan) ma na celu wypełnienie treści $\S 42$ AO. Można jednak zastanawiać się, czy rzeczywiście orzecznictwo dotyczące „całkowitego planu” (Gesamtplanrechtsprechung) nie jest doktryna orzecznicza, która mogłaby istnieć obok czy w oderwaniu od podstaw normatywnych. Uzasadnienia takiego postrzegania „całkowitego planu” można byłoby poszukiwać w interpretacji gospodarczej ustaw podatkowych.

W polskiej doktrynie na gruncie obowiązujących jeszcze regulacji ogólnej klauzuli przeciwko obejściu ustawy podatkowej (art. 24a i 24b Ordynacji podatkowej) prezentowany był pogląd, że ze względu na to, iż polskie przepisy używały określenia czynności odpowiedniej, która jest miarodajna dla określenia skutków podatkowych, polskie orzecznictwo podatkowe mogłoby w tym zakresie korzystać z dorobku doktryny i orzecznictwa niemieckiego, a także niemieckiej praktyki ${ }^{88}$. Aktualnie pogląd ten nie powinien być negowany tylko z tego względu, że na skutek wyroku Trybunału Konstytucyjnego o niekonstytucyjności norm zawartych we wskazanych wyżej przepisach Ordynacji podatkowej, trudno odszukać generalnej normy antyabuzywnej na wzór niemieckiej klauzuli generalnej.

Punktu łączącego postrzeganie zjawiska obejścia ustawy podatkowej w systemie prawa niemieckiego i polskiego można by upatrywać w stosowaniu gospodarczej interpretacji ustaw podatkowych, w szczególności w zakresie, $\mathrm{w}$ jakim jest ona wykorzystywania do walki z tym zjawiskiem ${ }^{89}$. Idąc dalej, wskazać można również na podobieństwa w sądowym scalaniu szeregu czynności podatników, w czym można upatrywać podobieństwo do niemieckiej koncepcji „całkowitego planu” (Gesamtplan) ${ }^{90}$.

mgr Jan Szczepański

Uniwersytet im. Adama Mickiewicza w Poznaniu

jan.szczepanski@amu.edu.pl

${ }^{88}$ H. Litwińczuk, op. cit., s. 247.

89 A. Mudrecki, Wykładnia gospodarcza w orzecznictwie Naczelnego Sadu Administracyjnego, w: Stanowienie $i$ stosowanie prawa podatkowego w Polsce. Optymalizacja podatkowa a obejście prawa podatkowego, Lublin 2012, s. 136.

90 Por. wyrok NSA w Gdańsku z 5 lipca 1996 r., I SA/Gd 433/96, Lex, nr 27224, a wyrok NSA w Gdańsku z 9 lutego 2000 r., I SA/Gd 2036/97, Lex, nr 40393, OSP 2001/10/153 z glosą: K. Zagrobelny, OSP 2001, z. 10, s. 520 . 


\title{
JUDICIAL APPROACH TO TAX AVOIDANCE IN GERMANY
}

\begin{abstract}
Summary
The paper focuses on the issue of anti-tax avoidance regulation in the German legal system and the important role of judicial decisions in the general discussion on this topic. The position of the legal doctrine as well as the general anti-abuse rule addressing the tax-avoidance problem, currently in force in Germany, are presented. This is followed by an analysis of the decisions delivered by the last instance finance and tax tribunal Bundesfinanzhof, including the so called Gesamtplanrechsprechung which presents, in detail, views and opinions of German courts regarding combatting tax avoidance practices. Such a structure of the paper aims to serve as comparative material and a voice in the discussion on the ways of tackling tax avoidance.
\end{abstract}


Copyright of Journal of Law, Economics and Sociology is the property of Faculty of Law and Administration of Adam Mickiewicz University in Poznan and its content may not be copied or emailed to multiple sites or posted to a listserv without the copyright holder's express written permission. However, users may print, download, or email articles for individual use.

Właścicielem praw autorskich do „Ruchu Prawniczego, Ekonomicznego i Socjologicznego” jest Wydział Prawa i Administracji Uniwersytetu im. Adama Mickiewicza w Poznaniu. Zawartość czasopisma nie może być kopiowana, przesyłana do innych stron internetowych bądź zamieszczana na blogach bez pisemnej zgody wydawcy. Niemniej artykuły można drukować, kopiować lub przesyłać w formie elektronicznej na własny użytek. 